\title{
PENERAPAN VIDEO BLOG QUESTION AND ANSWERS (Q\&A) UNTUK MENINGKATKAN HASIL BELAJAR SISWA: PENDEKATAN PENELITIAN TINDAKAN KELAS
}

\author{
Dini Octoria ${ }^{1}$, Sudiyanto ${ }^{2}$, Rena Zonaifi ${ }^{2}$ \\ ${ }^{1}$ Department of Economic Education, Faculty of Teacher Training and Education, Sebelas Maret University, \\ Indonesia \\ ${ }^{2}$ Department of Accounting Education, Faculty of Teacher Training and Education, Sebelas Maret University, \\ Indonesia \\ e-mail: noviadani.p@gmail.com
}

\begin{abstract}
Abstrak
Inovasi berkelanjutan merupakan suatu keharusan dalam penyelenggaraan pembelajaran dalam pendidikan formal. Hal tersebut juga didorong dengan kemajuan dan perkembangan teknologi yang sangat pesat sehingga mengharuskan pendidik memiliki kreatifitas dan inovasi tinggi dalam memberikan layanan dalam bentuk pembelajaran. Artikel ini membahas peningkatan hasil belajar siswa dalam penggunaan video blog question and answers (Q\&A) pada pembelajaran siklus akuntansi perusahaan jasa. Artikel ini merupakan hasil classroom Action Research. Data yang digunakan meliputi data kualitatif berupa informasi pelaksanaan kegiatan pembelajaran dengan menggunakan video blog Q \& A dan data kuantitatif berupa data hasil belajar baik kognitif, afektif dan psikomotorik. Sumber data diperoleh dari informan, peristiwa dan dokumen. Teknik pengumpulan data menggunakan observasi, wawancara dan tes. Hasil penelitian menunjukkan bahwa penerapan video blog Q \& A pada pembelajaran siklus akuntansi perusahaan jasa dapat meningkatkan hasil belajar peserta didik.
\end{abstract}

Kata Kunci: Video Blog Question And Answer; Hasil Belajar; Penelitian Tindakan Kelas

\section{PENDAHULUAN}

Sekolah Menengah Atas (SMA) sebagai satuan pendidikan yang menyelenggarakan pendidikan pada jalur pendidikan formal, harus melakukan inovasi terus menerus dan berkelanjutan agar dapat menghasilkan lulusan yang sesuai dengan standar kompetensi yang ditentukan. Untuk itu guru SMA di era revolusi industri 4.0 haruslah memiliki kreatifitas dan inovasi tinggi dalam memberikan layanan pembelajaran, khususnya dalam menggunakan model dan media pembelajaran yang sesuai dengan karakteristik materi ajar dan kebutuhan peserta didiknya, dan merujuk pada keterampilan 4C's yaitu: (1) Critical thinking and problem solving;(2) Creative and innovation; (3) Collaboration;(4) Communication.

Penggunaan smartphone yang tidak tepat guna membawa masalah dalam perkembangan teknologi di era revolusi industri 4.0. Smartphone selain sebagai alat bantu utama dalam berkomunikasi, dapat dijadikan media aktualisasi diri yaitu melalui media sosial seperti facebook, twitter, instagram, dan sosial media lainnya yang mungkin akan terus bertambah sesuai dengan perkembangan dan tuntutan zaman. Kondisi pada umunya, peserta didik menggunakan smartphone untuk menonton berbagai jenis video online melalui situs youtube, seperti menonton video musik, film, olahraga, pendidikan dan lain sebagainya. Jika diamati secara spesifik jumlah views pada video musik, film dan olahraga jauh lebih banyak daripada jumlah views pada video pendidikan. Kondisi tersebut tentu saja sangat memprihatinkan, karena peserta didik menggunakan smartphone lebih banyak untuk dunia hiburan, tidak untuk memfasilitasi pembelajaran secara digital.

Saat ini situs youtube sebetulnya sudah banyak berbagai pilihan video pembelajaran pada berbagai jenjang dan jenis pendidikan. Untuk peserta didik SMA, youtube juga banyak berisikan video-video pembahasan materi pelajaran ekonomi baik berupa teks, audio, audiovisual dan lain sebagainya. Akan tetapi, fasilitas tersebut kurang diminati peserta didik karena mereka lebih memilih video yang berisikan hiburan kekinian seperti video aktifitas pribadi para selebritis. Kondisi tersebut dapat dijadikan dasar dalam penerapan video yang digunakan pada bidang hiburan, untuk 
dimodifikasi dalam mata pelajaran ekonomi, yaitu pada materi pembelajaran siklus akuntansi di SMA.

Akuntansi sebagai salah satu bagian dalam mata pelajaran ekonomi yang diajarkan kepada peserta didik ketika duduk dikelas XII berdasarkan kurikulum 2013. Materi dalam akuntansi menuntut adanya kemampuan berpikir, sikap dan keterampilan dari peserta didiknya, khususnya untuk mata pelajaran siklus akuntansi yang berisikan pemahaman konsep dan juga keterampilan praktik dalam mengkomunikasikan transaksi keuangan menjadi informasi keuangan yang dapat digunakan oleh pihak intern dan ekstern perusahaan. Untuk itu guru perlu melakukan inovasi dalam penggunaan media pembelajaran, salah satunya dengan penerapan video blog question and answers (Q\&A) untuk meningkatkan hasil belajar siklus akuntansi di SMA.

Berdasarkan hasil observasi di SMA Muhammadiyah 1 Sukoharjo terkait kegiatan belajar mengajar di kelas XII IPS pada mata pelajaran ekonomi materi akuntansi, media yang digunakan kurang menarik dan inovatif. Guru hanya menggunakan media ajar berupa buku paket dan Lembar Kerja Siswa (LKS). Penggunaan media yang kurang menarik dan inovatif berakibat terhadap motivasi peserta didik untuk berpartisipasi aktif dalam kegiatan pembelajaran. Hal ini terlihat dari keterlibatan peserta didik, hanya barisan pertama sampai dengan barisan kedua dari depan yang cenderung aktif dalam mengikuti kegiatan pembelajaran. Barisan ketiga dan selanjutnya cenderung tidak memperhatikan dan memilih aktifitas lain seperti berbicara dengan temannya.

Selain itu, ketika guru meminta salah satu peserta didik untuk ke depan kelas memberikan penjelasan materi terlihat peserta didik tidak siap dan terbata-bata dalam menjelaskan materi yang telah dipelajari. Hal ini menunjukkan bahwa pemahaman terhadap materi yang diajarkan belum maksimal. Selanjutnya hasil pengolahan data pretest menunjukkan bahwa 42,86\% yang mencapai nilai Kriteria Ketuntasan Minimal (KKM) dan 57,14\% belum mencapai nilai KKM. Nilai KKM di SMA Muhammadiyah 1 Sukoharjo sebesar 70. Hasil tersebut menunjukkan bahwa pencapaian hasil belajar kognitif peserta didik belum maksimal.

Berdasarkan permasalahan yang telah diuraikan dalam latar belakang tersebut, artikel ini membahas peningkatan hasil belajar siswa dalam penggunaan video blog question and answers (Q\&A) pada pembelajaran siklus akuntansi perusahaan jasa.

\section{METODE}

Penelitian ini merupakan penelitian tindakan kelas (classroom Action Research). Penelitian ini dilaksanakan di SMA Muhammadiyah 1 Sukoharjo. Waktu penelitian direncanakan selama 2 siklus dengan masing-masing siklus terdiri dari 4 kegiatan yaitu 1) perencanaan, 2) pelaksanaan tindakan, 3) observasi, dan 4) refleksi. Subjek penelitian adalah peserta didik SMA Muhammadiyah 1 Sukoharjo. Pemilihan kelas berdasarkan hasil observasi awal yang telah dilakukan yang menunjukkan bahwa hasil belajar akuntansi belum optimal sehingga perlunya tindakan untuk meningkatkan hasil belajar akuntansi baik kognitif, afektif dan psikomotorik.

Penelitian ini menggunakan dua jenis data meliputi data kualitatif berupa informasi pelaksanaan kegiatan pembelajaran dengan menggunakan video blog Q \& A dan data kuantitatif berupa data hasil belajar baik kognitif, afektif dan psikomotorik. Sumber data diperoleh dari informan, peristiwa dan dokumen. Teknik pengumpulan data menggunakan observasi, wawancara dan tes. Observasi digunakan untuk mengetahui hasil belajar afektif peserta didik menggunakan instrument berupa lembar observasi. Wawancara digunakan untuk mendapatkan informasi kegiatan pembelajaran sebelum dan sesudah diterapkannya video blog Q \& A pada setiap siklus yang dilaksanakan. Tes berupa tes uraian untuk mengetahui hasil belajar kognitif dan tes unjuk kerja untuk mengetahui hasil belajar psikomotorik peserta didik.

Instrumen yang digunakan dalam penelitian telah diuji validitas dan reabilitas agar mendapatkan kredibilitas dan derajat kepercayaan atau derajat kebenaran penelitian. Uji validitas instrumen yang digunakan dalam penelitian ini menggunakan uji validitas isi yang dapat dilakukan menggunakan satu dari tiga metode yaitu menelaah butir instrumen meminta pertimbangan ahli. Instrumen berupa lembar observasi, pedoman wawancara, tes berupa tes uraian dan tes unjuk kerja 
dalam penelitian telah diuji kevalidannya oleh tim ahli yang ditunjuk peneliti. Selanjutnya, pengujian reabilitas instrumen menggunakan teknik alpha. Reabilitas menunjuk kepada konsistensi hasil pengukuran jika dilakukan pengukuran berulang-ulang pada individu-individu atau kelompokkelompok dalam suatu populasi.

Penelitian ini tidak hanya dilakukan uji validitas instrumen tetapi juga uji validitas data untuk pengecekan atau pemeriksaan keabsahan dari data yang diperoleh dengan menggunakan teknik triangulasi metode. Maka yang akan digunakan dalam uji validitas data ini dari informan (narasumber) melalui wawancara, kondisi lokasi maupun aktivitas melalui observasi, serta melakukan tes untuk mengetahui hasil belajar peserta didik. Analisis data yang digunakan adalah analisis statistik deskriptif untuk data kuantitatif berupa mean untuk melihat ketuntasan hasil belajar, sedangkan data kualitatif data kualitatif dianalisis dengan model interaktif (interactive model) yaitu data kualitatif diinterpretasikan dan dihubungkan dengan data kuantitatif sebagai dasar mendeskripsikan keberhasilan pelaksanaan penggunaan video blog Q \& A untuk meningkatakan hasil belajar peserta didik. Indikator penelitian yang hendak dicapai yaitu $80 \%$.

\section{HASIL DAN PEMBAHASAN \\ Hasil}

Pemerolehan data pratindakan sangat penting untuk mengetahui kondisi sebelum tindakan diberikan di kelas. Berikut hasil identifikasi masalah yang dapat dipaparkan yaitu ditinjau dari segi peserta didik diantaranya 1) peserta didik kurang berpartisipasi aktif dalam pembelajaran, 2) peserta didik kurang kesiapan dalam pembelajaran akuntansi dan 3) peserta didik untuk pencapaian hasil belajar belum maksimal, sedangkan ditinjau dari guru diantaranya 1) media pembelajaran yang digunakan guru terbatas pada media visual berupa teks yaitu buku paket dan LKS, 2) metode pembelajaran yang digunakan berupa ceramah, diskusi dan tanya jawab tanpa pemanfaatan media pembelajaran, dan 3) pemanfaatan tekhnologi disekitar belum maksimal, salah satunya pemanfaatan gadget dalam pembelajaran masih terbatas untuk browsing materi.

Selanjutnya, terkait hasil belajar pratindakan materi akuntansi dapat dilihat pada tabel I.

\begin{tabular}{lccc}
\hline Hasil Belajar & $\begin{array}{c}\text { Indikator } \\
\text { Kinerja }\end{array}$ & $\begin{array}{c}\text { Ketercapaian } \\
(\%)\end{array}$ & Keterangan \\
\hline Afektif & 80 & 50,00 & Belum tercapai \\
\hline Psikomotorik & 80 & 37,50 & Belum tercapai \\
\hline Kognitif & 80 & 28,00 & Belum tercapai \\
\hline Rata-Rata & 80 & 38,50 & Belum tercapai \\
\hline
\end{tabular}

(Sumber: Data primer yang diolah, 2019)

Berdasarkan analisis dan situasi, menunjukkan bahwa hasil belajar baik afektif, psikomotorik dan kognitif akuntansi belum mencapai indikator kinerja penelitian, sehingga perlu upaya untuk meningkatkan hasil belajar akuntansi. Upaya yang dilakukan dengan menerapkan video blog Q\&A pada pembelajaran akuntansi sehingga diharapkan adanya peningkatan hasil belajar peserta didik baik afektif, psikomotorik dan kognitif peserta didik.

\section{Tindakan Siklus I}

Hasil tindakan Siklus I yang telah dilakukan menunjukkan bahwa penerapan video blog Q \& A dalam kegiatan pembelajaran dapat meningkatkan hasil belajar peserta didik. peningkatan hasil belajar diketahui dari hasil pengolahan data dari lembar observasi dan tes pada siklus I dibandingan pada bratindakan meskipun belum mencapai indikator kinerja penelitian. Berikut dapat dilihat hasil ketercapaian indikator hasil belajar peserta didik pada tabel II. 
Tabel II. Ketercapaian Hasil Belajar Akuntansi Siklus I

\begin{tabular}{lccl}
\hline Hasil Belajar & $\begin{array}{c}\text { Indikator } \\
\text { Kinerja }\end{array}$ & $\begin{array}{c}\text { Ketercapaian } \\
(\%)\end{array}$ & Keterangan \\
\hline Afektif & 80 & 67,85 & Belum tercapai \\
\hline Psikomotorik & 80 & 64,29 & Belum tercapai \\
\hline Kognitif & 80 & 71,43 & Belum tercapai \\
\hline Rata-Rata & 80 & 67,86 & Belum tercapai \\
\hline
\end{tabular}

(Sumber: Data primer yang diolah, 2019)

Selain itu, temuan lain yang dapat dijabarkan pada siklus I diantaranya: 1) prosedur penerapan video blog $\mathrm{Q} \& \mathrm{~A}$ belum sepenuhnya dipahami baik oleh guru maupun peserta didik. 2) masih terdapat peserta didik yang belum memahami materi dan sering tertukar ketika menjawab pertanyaan yang diberikan, dan 3) peserta didik kurang percaya diri membuat video blog Q \& A karena merasa kurang percaya diri.

Berdasarkan hasil ketercapaian indikator kinerja pada siklus I di atas, dapat diketahui bahwa motivasi dan hasil belajar siswa belum mencapai indikator kinerja penelitian sebesar $85 \%$. Oleh karena itu, pelaksanaan pembelajaran perlu dilanjutkan ke siklus selanjutnya, yaitu siklus II guna memperbaiki pencapaian masing-masing indikator yang belum tercapai serta memperbaiki temuantemuan yang terjadi pada siklus I sehingga dapat menjadi lebih baik pada siklus II.

\section{Tindakan Siklus II}

Hasil tindaka siklus II yang telah dilakukan menunjukkan bahwa penerapan video blog Q \& A dalam kegiatan pembelajaran dapat meningkatkan hasil belajar peserta didik. Peningkatan hasil belajar diketahui dari hasil pengolahan data dari lembar observasi dan tes pada siklus I dibandingan pada pratindakan meskipun belum mencapai indikator kinerja penelitian. Berikut dapat dilihat hasil ketercapaian indikator hasil belajar peserta didik pada tabel III.

Tabel III. Ketercapaian Hasil Belajar Akuntansi Siklus II

\begin{tabular}{lccl}
\hline Hasil Belajar & $\begin{array}{c}\text { Indikator } \\
\text { Kinerja }\end{array}$ & $\begin{array}{c}\text { Ketercapaian } \\
(\%)\end{array}$ & Keterangan \\
\hline Afektif & 80 & 87,50 & Tercapai \\
\hline Psikomotorik & 80 & 82,50 & Tercapai \\
\hline Kognitif & 80 & 85,00 & Tercapai \\
\hline Rata-Rata & 80 & 85,00 & Tercapai \\
\hline
\end{tabular}

(Sumber: Data primer yang diolah, 2019)

Selain itu, temuan lain yang dapat dijabarkan pada siklus II diantaranya: 1) peserta didik masuk ke dalam kelas sesuai dengan jadwal yang telah ditentukan serta kelas lebih kondusif dalam pembelajaran, 2) peserta didik yang mengalami kesulitan sudah dapat teratasi karena guru melakukan pendekatan secara langsung ketika pembelajaran, dan 3) video blog Q \& A yang dibuat sudah lebih baik dari sebelumnya dan peserta didik lebih percaya diri dalam menggunakan kamera untuk pembelajaran.

Berdasarkan hasil ketercapaian indikator kinerja pada siklus II di atas, dapat diketahui bahwa hasil belajar peserta didik sudah mencapai indikator kinerja penelitian sebesar $80 \%$. Oleh karena itu, pelaksanaan tindakan tidak dilanjutkan ke siklus selanjutnya.

\section{PEMBAHASAN}

Deskripsi hasil tindakan yang telah dipaparkan sebelumnya, dapat diketahui bahwa adanya peningkatan hasil belajar peserta didik setelah diterapkannya video blog Q \&A dari pratindakan, siklus I dan siklus II. Peningkatan hasil belajar tidak hanya hasil belajar kognitif melainkan afektif dan psikomotorik peserta didik.Data pratindakan menunjukkan bahwa hasil belajar peserta didik 
belum mencapai indikator kinerja sehingga diperlukan tindakan yang dilakukan. Penerapan video blog Q \& A menjadi pilihan solusi dalam permasalahan yang merupakan hasil temuan di lapangan. Penggunaan video dapat mengkondisikan peserta didik untuk aktif. Hal ini terjadi karena tidak hanya bekerja secara individu melainkan dilatih untuk saling bekerjasama dan berkompetisi dalam pembelajaran. Selain itu, penerapan video tidak hanya akan mempengaruhi hasil belajar kognitif melainkan dari afektif dan psikomotorik peserta didik. Sejalan dengan itu hasil temuan Shoufan (2018) bahwa literature memberikan bukti untuk efektivitas video pendidikan online pada peserta didik juga fitur umum dari video seperti cara produksi dan durasi video. Hal-hal tersebut yang membuat peserta didik tidak berpikir secara individu melainkan secara bersama-sama membuat video blog Q \& A.

Hasil penerapan tindakan dalam siklus I menunjukkan bahwa adanya peningkatan hasil belajar peserta didik baik kognitif, afektif dan psikomotorik akan tetapi peningkatan yang dicapai belum mencapai indikator kinerja penelitian yang diharapkan. Peningkatan dapat terjadi dilihat dari partisipasi aktif peserta didik yang antusias dalam menggunakan HP yang dimiliki dalam kegiatan pembelajaran. Meskipun ada beberapa peserta didik yang malu-malu untuk beradegan di depan kamera. Hal ini dapat dilihat dari video yang dibuat untuk komunikasi peserta didik masih terbatabata dan kurang percaya diri. Penggunaan video blog Q\&A membangkitakan minat peserta didik untuk berpartisipasi aktif dalam kegiatan pembelajaran. hal ini sejalan dengan temuan dari Brame (2016) menyatakan bahwa video yang efektif dirancang dan diimplementasikan dengan menyeimbangkan tiga elemen: beban kognitif, keterlibatan siswa, dan pembelajaran aktif.

Selanjutnya deskripsi hasil tindakan siklus II menunjukkan bahwa adanya peningkatan hasil belajar peserta didk melalui penerapan video blog Q \& A dibanding hasil tindakan siklus I. Hal ini dapat terjadi mengingat perencanaan siklus II lebih matang dibandingkan dalam siklus I setelah dilakukannya evaluasi. Peningkatan pada siklus II sudah mencapai indikator kinerja penelitian sehingga tidak dilanjutkan pemberian tindakan pada siklus selanjutnya. Video blog Q \& A membuat suasana pembelajaran lebih aktif dan kondusif. Hal ini sejalan dengan hasil temuan D'Aquila \& Mattia (2019) menyatakan bahwa penggunaan video meningkatkan kinerja peserta didik. Video memungkinkan peserta didik untuk melihat materi secara selektif dan membantu peserta didik sesuai dengan gaya belajar yang beragam untuk memahami konsep dan menyimpan informasi.

\section{PENUTUP}

Hasil dan pembahasan pada penelitian yang telah dipaparkan, maka dapat diambil kesimpulan bahwa penerapan video blog Q \& A pada pembelajaran siklus akuntansi perusahaan jasa dapat meningkatkan hasil belajar peserta didik. Berdasarkan hasil penelitian, diharapakan guru mampu menciptakan dan memodifikasi model pembelajaran dengan memanfaatkan media pembelajaran agar peserta didik termotivasi dalam mengikuti kegiatan pembelajaran sehingga berdampak pada hasil belajar peserta didik dan sekolah memberikan dukungan terkait pembelajaran yang memanfaatkan IT sehingga peserta didik dapat menambah wawasan terkait dengan Gadget yang dimiliki.

\section{DAFTAR PUSTAKA}

Anderson, L. W., \& Krathwohl, D. R. (2001). A Taxonomy for Learning Teaching and Assessing. New York: Longman

Anita, S. 2012. Media Pembelajaran. Jakarta: Yuma Pustaka

Arends, Richard I. 2004. Learning To Teach. New York: McGraw Hill

Arsyad, A. 2010, Media Pembelajaran. Jakarta: PT. RajaGrafindo.

Brame, C. (2016). Effective educational videos: Principles and guidelines for maximizing student learning from video content. CBE-Life Sciences Education, 15(4).

Budiyono. 2015. Pengantar Penilaian Hasil Belajar. Surakarta: UNS Press 
D'Aquila, J.M., Wang, D., \& Mattia, A. 2019. Are instructor generated YouTube videos effective in accounting classes? A study of student performance, engagement, motivation, and perception. Journal of Accounting Education, 47, 63-74.

Miller, M. D., Linn, R. L., \& Gronlund, N. E. 2009. Measurement and Assessment in teaching. Upper Saddle River. New Jersey: Pearson.

Prensky, M. 2001. Digital Natives, Digital Immigrants. MCB University Press, Vol 9 No. 5, October 2001.

Shoufan, A. 2019. Estimating the cognitive value of YouTube's educational videos: A learning analytics approach, Computer in Human Behavior, 92, 450-458.

Smaldino, Sharon E., Lowther, Deborah L., Mims, C. 2019. Instructional Technology and Media for Learning 12th Edition. New York: Pearson

Undang Undang No. 14 Tahun 2005 tentang Guru dan Dosen.

Undang Undang No. 20 Tahun 2003 tentang Sistem Pendidikan Nasional. 